\title{
Historical perspectives of The American Association for Thoracic Surgery: John C. Jones (1903-1976)
}

\author{
Landi M. Cranstoun, MD, ${ }^{\mathrm{a}}$ and J. William Gaynor, $\mathrm{MD}^{\mathrm{b}}$
}

Many presidents of The American Association for Thoracic Surgery (AATS) have used their presidential addresses to give their perspectives on topics of philosophic interest. John C. Jones, 45th president of the AATS, began his address by noting, "Philosophy and philosophic discussion have not been my forte." Instead, he proceeded to give a highly technical discussion of his experience with repair of patent ductus arteriosus (PDA). ${ }^{1}$ The intensely practical orientation apparent in his presidential address was a hallmark of his surgical career.

John Jones was born November 18, 1903, in Steubenville, Ohio (Figure 1). His family had emigrated from Wales, and he was the only one of his siblings to be born in the United States. ${ }^{2}$ Jones graduated from Ohio Wesleyan University in 1925. After completing his medical education at the University of Michigan, he began training in general surgery at the Cleveland Clinic. He developed an early interest in surgery of the chest and subsequently completed the thoracic surgery training program at the University of Michigan under Dr John Alexander (17th AATS president), thus becoming one of the first surgeons to be formally trained in thoracic surgery. In 1934, Dr Jones moved to Los Angeles and began his surgical career in private practice. He became affiliated with the Children's Hospital of Los Angles and was appointed the first chief of thoracic and cardiovascular surgery in 1939. Jones performed the first pediatric cardiac operation on the West Coast in March that year; unfortunately, in 1939 he also was diagnosed with tuberculosis and confined to a sanatorium for the next 2 years. ${ }^{2}$

At the time Jones began his clinical practice, tuberculosis constituted a large portion of thoracic surgery. Jones cared for many patients with tuberculosis and performed many pulmonary resections in both children and adults. Patients sought him out because of his experience with tuberculosis and because he had no fear of operating for this often very complicated disease. Jones meticulously documented his patients' histories and the details of their care, which he

From the Division of Cardiovascular Surgery, ${ }^{\mathrm{a}} \mathrm{Hospital}$ of the University of Pennsylvania, Philadelphia, Pa; and the Division of Cardiothoracic Surgery, ${ }^{\mathrm{b}}$ Children's Hospital of Philadelphia, Philadelphia, Pa.

Disclosures: Authors have nothing to disclose with regard to commercial support.

Received for publication Dec 27, 2012; accepted for publication Jan 11, 2013; available ahead of print March 7, 2013.

Address for reprints: J. William Gaynor, MD, Division of Cardiothoracic Surgery, Children's Hospital of Philadelphia, 34th St and Civic Center Blvd, Philadelphia, PA 19104 (E-mail: gaynor@email.chop.edu).

J Thorac Cardiovasc Surg 2013;145:1170-2

$0022-5223 / \$ 36.00$

Copyright (C) 2013 by The American Association for Thoracic Surgery

http://dx.doi.org/10.1016/j.jtcvs.2013.01.015

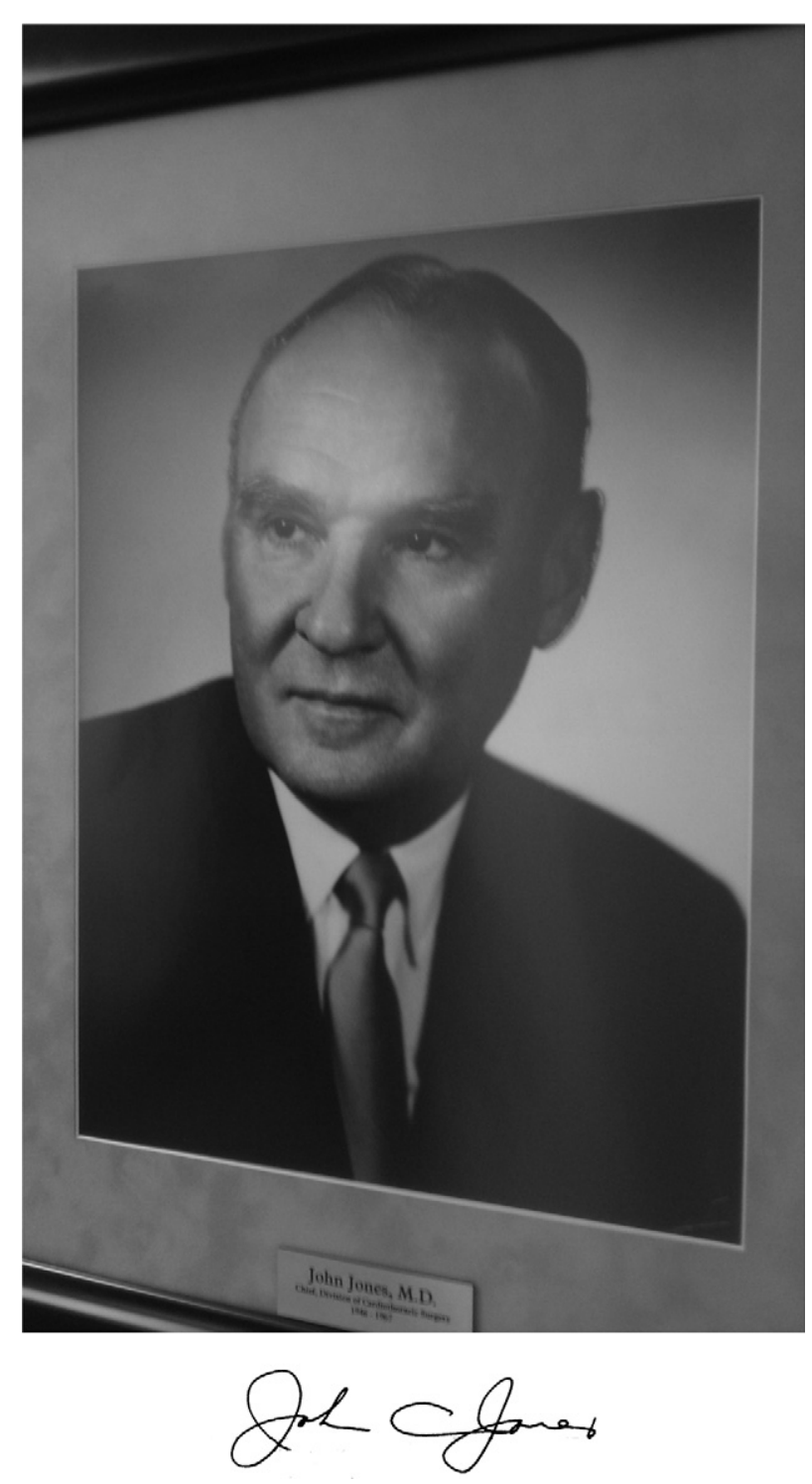

FIGURE 1. Portrait of Dr John Jones, currently on display at the Children's Hospital of Los Angeles. Courtesy of Dr Winfield Wells.

later published as a case series. ${ }^{3}$ At the time, medical therapy for tuberculosis was under development and, although promising in adults, had not been shown to be effective in children. The sanatorium was still seen by many groups as critical to successful treatment. Jones, however, expressed concern about the declining standards of children's sanatoria and lamented, "Frequent visiting hours, the blaring of radios and television sets, teaching exercises, play therapy, and various forms of daily entertainment have 

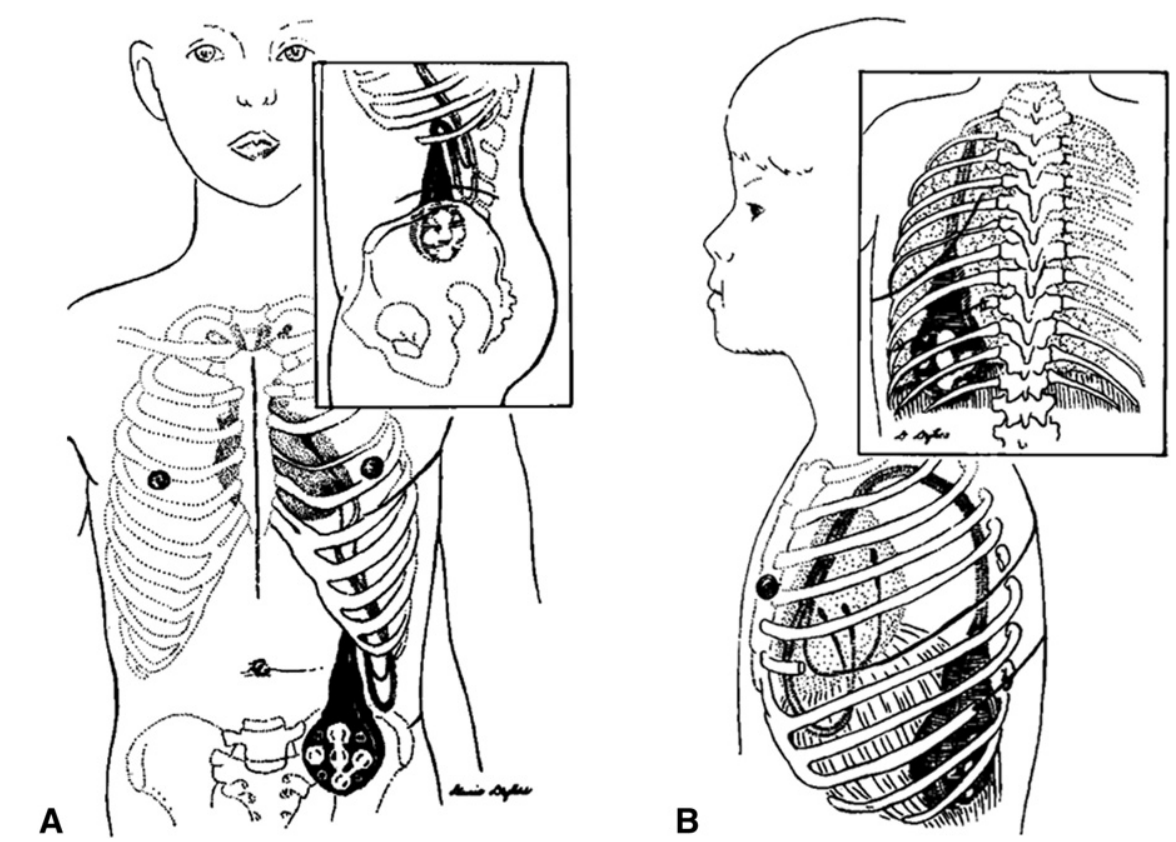

FIGURE 2. A, Intrapelvic placement of a pacemaker. B, Intrathoracic placement of a pacemaker. Reprinted with permission. ${ }^{8}$

contributed to the development of an atmosphere of undisciplined revelry." ${ }^{3} \mathrm{He}$ was uniquely qualified to comment, having spent 2 years as a patient himself. Jones clearly differentiated the pediatric from the adult patient, in terms both of ideal timing of surgery and of the technical aspects. Also notably, Dr Jones performed the first pulmonary resection for coccidiomycosis. ${ }^{2}$

Despite beginning his career in private practice, Dr Jones was deeply interested in training the next generation of thoracic surgeons. He became a leader in thoracic surgical education and initiated one of the early thoracic surgery training programs in 1948. Dr Quentin Stiles, AATS secretary from 1983 to 1988 , was one of his trainees and a long-time associate. The training program was based at the Hospital of the Good Samaritan and the Children's Hospital of Los Angeles. The program evolved from an initial preceptorship model to a fully accredited program. Dr Jones's method for training fellows was to have them assist him during surgery rather than help the residents perform the procedure as operating surgeon. When Dr Stiles was asked how Jones might respond to the current trend toward early specialization in cardiac surgery, he responded, "[Dr Jones] was the sort of guy who did everything, because he had to ... it's just how it was."

Jones is best known for his innovative work in surgery for PDA. He was one of the earliest surgeons to successfully ligate a PDA, performing his first case in 1939 soon after Dr Gross's initial case. Jones chose to focus his AATS presidential address in 1965 on surgery for PDA. ${ }^{1}$ He felt strongly that is was essential to educate young surgeons on the appropriate surgical care of PDA before the first case so that they could minimize complications and, when complications occurred, address them appropriately. Jones was aghast when "[he] heard of a death from hemorrhage on the operating table when a young, inexperienced resident performed his first ductus operation in a large hospital where ... ductus surgery [was] beneath the dignity of the upper echelon of staff." His address focused on his personal series of 909 patients, ranging in age from 10 days to 60 years. He reviewed his successes, which were many, as well as his disasters, which were few but, to quote the master, were in all cases "traumatic to both surgeon and patient." On the basis of his formidable experience, Jones advocated division of the PDA rather than ligation, surgery at an early age before the development of pulmonary hypertension, and awareness of the possibility of bacterial bloodstream infection and mycotic aneurysm, which in his experience had been the cause of several catastrophes.

Dr Jones's contributions in cardiovascular surgery were not limited to PDA. In 1971, he reviewed his experience with 390 patients with aortic coarctation. ${ }^{4}$ His preferred method of repair was resection with end-to-end anastomosis; he rarely used interposition grafts. He also reported an extensive experience with open resection for right ventricular outflow tract obstruction. ${ }^{5}$ Dr Stiles remembers that $\mathrm{Dr}$ Jones never became comfortable with cardiopulmonary bypass and preferred the use of topical hypothermia with inflow occlusion. ${ }^{6,7}$ Jones was also one of the early advocates of the use of synchronous rather than fixed-rate pacemakers in children, citing more normal cardiac function and avoidance of bizarre rhythms from pacemaker competition should sinus rhythm return. ${ }^{8}$ Concerned that there was not enough subcutaneous tissue in children for appropriate containment of the very large synchronous 
generator, he avoided subcutaneous placement, offering several creative alternatives. In one active boy he used intrapelvic placement to avoid direct blows to the generator (Figure 2, A); in others, he placed the generator inside the thoracic cavity (Figure 2, $B$ ).

Every surgeon must someday retire, and some have better timing than others. Dr Stiles related the story of Dr Jones's last operation. It was a particularly difficult case, "real pick and shovel kind of work," with Dr Stiles, then a young attending who assisted Dr Jones with the operation. At the end of the case, Jones turned to Stiles unexpectedly and said, "I don't know why I do these kinds of cases when I've got a guy like you around!' That was the last time Dr Jones operated. After that, he would see patients in clinic and then introduce his colleague as the one who would be performing the operation. He always stopped by the operating room, though, to put forth an encouraging word.

By his own admission not a philosopher and himself responsible for only a few "firsts," Dr Jones's primary legacy was in the construction of large case series documenting his ongoing refinement of operative techniques and in the training of the next generation of thoracic surgeons. When asked what Dr Jones would most have wanted to be remembered as, Stiles replied without hesitating, "A really good surgeon."

\section{References}

1. Jones JC. Twenty-five years' experience with the surgery of patent ductus arteriosus. J Thorac Cardiovasc Surg. 1965;50:149-65.

2. Lindesmith GG. John C. Jones (1903-1976). J Thorac Cardiovasc Surg. 1977;73: 813-4.

3. Rothman PE, Jones JC, Peterson HG Jr. Endoscopic and surgical treatment of pulmonary tuberculosis in children. AMA J Dis Child. 1960;99:315-28.

4. Lindesmith GG, Stanton RE, Stiles QR, Meyer BW, Jones JC. Coarctation of the thoracic aorta. Ann Thorac Surg. 1971;11:482-97.

5. Meyer BW, Jones JC, Lindesmith GG. The surgery of congenital defects obstructing the outflow of the right ventricle. Am J Surg. 1963;106:259-66.

6. Gordon AS, Jones JC, Luddington LG, Meyer BW. Deep hypothermia for intracardiac surgery. Experimental and clinical use without an oxygenator. Am J Surg. 1960;100:332-7.

7. Gordon AS, Meyer BW, Jones JC. Open-heart surgery using deep hypothermia without an oxygenator. J Thorac Cardiovasc Surg. 1960;40:787-99.

8. Lindesmith GG, Stiles QR, Meyer BW, Jones JC, Stanton RE. Experience with an implantable synchronous pacemaker in children. Ann Thorac Surg. 1968;6: 358-64. 